\title{
Language Learning Strategies: Contrasting English Department and Non-English Department Students
}

\section{Sheila Agustina}

Universitas Muhammadiyah Sidoarjo, Indonesia

Email:_agustinasheila27@gmail.com

\begin{abstract}
It is a fact that language learning strategies can help learners to learn a language successfully. English learners who employ certain language learning strategy are believed to be able to master the language better and faster than those who do not employ any strategies or those who are not aware of their learning strategies. While learning strategies may affect the success of a language learner, a learner's 'choice' of certain strategy can be influenced by one's study background. Some previous studies have verified it by examining language learning strategies used by students of English Department and students of non-English Department using Oxford's Strategy Inventory for Language Learning (SILL). Thus, with the same instrument, this research aims to prove the presence of the students' differences in using the strategies. This research is under a survey research design with students' responses as the main data and questionnaires as the instrument. The finding indicates that English Department students make use of social strategies the most, while non-English Department students generally use metacognitive strategies. The implication of this research is to give valuable inputs for English lecturers of both settings in subjecting their students according to the findings of each strategy's use.
\end{abstract}

Keywords: language learning strategy; English Department; Non-English Department

\section{DOI $\quad$ : $10.24903 /$ bej.v4i1.843}

\begin{tabular}{|l|l|l|}
\hline Received & $:$ & December 2021 \\
\hline Accepted & $:$ & January 2022 \\
\hline Published & $:$ & February 2022 \\
\hline
\end{tabular}

Authors retain copyright and grant the journal right of first publication with the work simultaneously licensed under a Creative Commons Attribution 4.0

Copyright and License International License that allows others to share the work with an acknowledgement of : the work's authorship and initial publication in this journal. 


\section{INTRODUCTION}

Many studies revealed that second or foreign language learners are actively involved in learning the language. As non-native English speakers, learners sometimes encounter barriers to learn the language. Some students may successfully acquire English well and rapidly, but some other students may not. Many successful language learners are believed to employ some learning strategies to help them acquiring the language. They make use of certain techniques of learning to perform better in second or foreign language. A study conducted by Yustitiasari, Junining, and Sahiruddin (2020) reported that a strategy called compensation strategy was frequently used by high proficient learners.

Ellis (1997:76) explains that "learning strategies are the particular approaches or techniques that learners employ to try to learn an L2". Meanwhile, Oxford (1990:8) defines learning strategies as "specific actions taken by the learner to make learning easier, faster, more enjoyable, more self-directed, more effective, and more transferable to new situations". Later, Oxford (1990) developed a new language learning strategy system, which includes two main classifications: direct strategies and indirect strategies. Direct strategies are specific ways that involve use of language, while indirect strategies do not directly involve using the language, but they support language learning. A study conducted by Ang, Embi, and Yunus (2017) once acknowledged that successful language learners employed more indirect strategies.

In broader sense, these strategies can be specified as follows (Oxford, 1990:14):

1. Memory strategies for remembering and retrieving new information,

2. Cognitive strategies for understanding and producing the language,

3. Compensatory strategies for using the language despite lack of knowledge,

4. Metacognitive strategies for coordinating the learning process,

5. Affective strategies for regulating emotions, and

6. Social strategies for learning with others.

Based on this list of strategies, Oxford (1990) suggested Strategy Inventory for Language Learning (SILL) as useful instrument designed to test the learners' strategy use. The SILL is highlighted here because it is the most widely used language learning strategyassessment instrument in the world. Putri and Wahyuni (2019) used this tool to find out that cognitive strategies were the most common strategy in learning vocabulary used by high achiever students. The SILL has two forms: a 50-item questionnaire for people learning 
English as a second or foreign language and an 80-item questionnaire for native English speakers learning other languages.

A student is believed to have certain language learning strategies different from the others. Many factors influence students using language learning strategies, such as age, sex, attitude, motivation, aptitude, learning stage, task requirements, teacher expectation, learning styles, individual differences, motivation, cultural differences, beliefs about language learning, and language proficiency. According to a study, gender was confirmed to be a significant factor that influenced learners in using social strategies (Cong-Lem, 2019). There are many variables that affect the language learning strategies of different students, one of which is cultural background. Oxford and Burry-Stock (1995) emphasizes that different cultural groups use particular kinds of strategies at different levels of frequency.

In university level, students of English Department usually get introduced to EFL or English as a Foreign Language. It is the use or study of English by speakers with different native languages. On the other hand, ESP or English for Specific Purposes is a sphere of teaching English language to non-English Department students. ESP teaching actually has much in common with EFL. In difference, EFL is usually taught for students to learn English intentionally for proficiency, but ESP is for those who learn English to develop their English skills in regard to professional work situation or other specific purposes. It is commonly found that EFL students learn English because they have to, and they want to. In other way, ESP students think that English is not their area and, therefore, it is not too necessary for them to learn English. The problem of teaching English to ESP students because of this 'unrelation to the students' major' was also encountered and described by Masyhud (2018) in his work. Students of EFL may share the same cultural background, as well as among the ESP students. The cultural background of EFL and ESP students will lead to different way of learning English. Due to the notion that different students may use different strategies, it is assumed that EFL and ESP students also employ the strategies differently.

Some previous studies indicated that there were only slight differences between English Department and non-English Department students' learning strategies. Hoseini and Tabatabaei (2014) performed a survey to explore differences in language learning strategies used by Iranian EFL and ESP learners when dealing with collocations in reading passages, and the results revealed that EFL participants preferred social strategies, while the ESP group resorted to cognitive strategies. However, more studies claimed that both ESP and EFL students apply the same meta-cognitive strategies more frequently. Alqahtani and Alhebaishi 
(2010) who conducted a study on political sciences studies found that the students used metacognitive strategies the most. Moreover, Hapsari (2019) showed that the students of English Language Education UII also used meta-cognitive strategies highly. It means that these students prefer to plan clear goals, control, review, and evaluate their learning (Sartika, Santihastuti, Wahjuningsih, 2019).

Based on the previous studies, the present study is inspired to investigate Indonesian English Department and non-English Department students' differences in using language learning strategy. The present study examines the use of language learning strategies between the two-group students using the same tools (Oxford's SILL questionnaire). The result is then compared with the previous studies, whether they have the same characteristics in utilizing the strategies or not. Grounded on the above consideration, the research questions are formulated in the following: (1) What language learning strategies are used by the English Department students the most often? And (2) what language learning strategies are used by non-English Department students most often?

\section{METHODOLOGY}

\subsection{Research Design}

This study is conducted by performing a survey to participants. Accordingly, this research was under descriptive research with survey research design. This research design was selected for there was no such manipulation in the variables, and data were usually analyzed using basic simple statistical formula (Latief, 2013). The data were the questionnaire results from students which would later be explained descriptively in findings. The questionnaire instrument of this study is adopted from Strategy Inventory for Language Learning (SILL) proposed by Rebecca Oxford (1990). This form of strategy inventory is intended for students of second or foreign language. It consists of 50 close-ended questions with a five-point Likert scale, ranging from 1 to 5. For the implementation, the participants read the items and then give a scale of 1 to 5 as response based on the instruction given. The results of students completing the questionnaire are the basis of determining language learning strategy utilized by students.

\subsection{Participants}

The participants involved in this study are 19 students of English Department Brawijaya University Malang, East Java, and 19 students of Accounting Department UIN 
Maulana Malik Ibrahim Malang, East Java. These students are divided into two groups. The sample of 19 students of Brawijaya University are taken to English Department students. On the other hand, 19 students of UIN Maulana Malik Ibrahim are chosen as a representative of non-English Department students. The reason of selecting the participants is simply because of the accessibility and practicality. The present study involves equal number of group participants so that the result of analysis is expected to be more valid.

\subsection{Data Collection}

In this study, the data were collected in two main steps. First, the researcher carried out a survey by distributing two kinds of questionnaire related to language learning strategy. Then, the results of the questionnaire were deciphered into numerical scores to read the students' responses.

In this study, the questionnaire for both groups are distinguishable. The questionnaire for English Department students is the English version of SILL by Oxford (1990), while Indonesian version of SILL are provided for the non-English Department students. As a consideration, the mother-tongue version is made to ease the non-English Department students to understand each item, since they are not learning English thoroughly.

The participants are asked to fill the SILL questionnaire which is divided into six parts. These parts are grouped based on the six language learning strategies categorized by Oxford (1990). The first part (Part A) containing 9 items of question is for memory strategies; the second part (Part B) containing 14 items of question is for cognitive strategies; the third part (Part C) containing 6 items of question is for compensatory strategies; the fourth part (Part D) containing 9 items of question is for metacognitive strategies; the fifth part (Part E) containing 6 items of question is for affective strategies; and last, the six part (Part F) containing 6 items of question is for social strategies. The dominant learning characteristics of the students are determined by the mean scores of each part.

\subsection{Data Analysis}

After collecting the data, the researcher did the process of data analysis. First, the researcher read the numerical scores from the students' questionnaires and counted the mean scores of each datum. Then, those numbers were interpreted descriptively. In informing the readers about the result of the questionnaire, the researcher formulated the numbers into neat and ordered explanation. Finally, the researcher drew a conclusion based on the findings. To 
conclude, the researcher represented the English Department and non-English Department students' pattern of strategies' use.

\section{FINDINGS}

This part presents the findings from the data obtained. After collecting the data, the questionnaire's mean scores of each student are measured. It is best to find out the language learning strategies used by each student. The total mean scores of the students are also useful to draw a dominant strategy utilized by students. The findings are presented into two subparts, regarding the subjects of the study.

\subsection{Results of English Department Students' Questionnaire}

The result of questionnaire taken from English Department students of Brawijaya University is as shown in Table 1.

Table 1. The English Department Students' Use of Language Learning Strategies (Mean Score)

\begin{tabular}{ccccccc}
\hline \multirow{2}{*}{ Students } & \multicolumn{7}{c}{ Mean } \\
\cline { 2 - 7 } & Part A & Part B & Part C & Part D & Part E & Part F \\
\hline $\mathbf{1}$ & 2.667 & 3.214 & 3.167 & 3.111 & 3 & 3 \\
\hline $\mathbf{2}$ & 3.778 & 3.142 & 4.667 & 3.222 & 4.167 & 3.167 \\
\hline $\mathbf{3}$ & 4.333 & 3.928 & 3.333 & 3.111 & 3.333 & 3.333 \\
\hline $\mathbf{4}$ & 2.667 & 3.286 & 3.667 & 4.222 & 3 & 3.833 \\
\hline $\mathbf{5}$ & 3.444 & 3.786 & 4 & 4 & 4 & 4 \\
\hline $\mathbf{6}$ & 4.556 & 3.928 & 4.5 & 4.111 & 4.333 & 3.833 \\
\hline $\mathbf{7}$ & 2.889 & 2.643 & 2.667 & 1.889 & 2.167 & 2.333 \\
\hline $\mathbf{8}$ & 3.111 & 2.928 & 3 & 3.444 & 3.833 & 4 \\
\hline $\mathbf{9}$ & 4.333 & 3.928 & 3.5 & 3.889 & 4 & 4 \\
\hline $\mathbf{1 0}$ & 3.444 & 3.286 & 3.333 & 3.333 & 3.667 & 3.333 \\
\hline $\mathbf{1 1}$ & 4.222 & 4.286 & 4.5 & 4.667 & 4.167 & 4.167 \\
\hline $\mathbf{1 2}$ & 4.111 & 4 & 4.167 & 4 & 4.167 & 4.167 \\
\hline $\mathbf{1 3}$ & 3.333 & 3.143 & 2.667 & 3.778 & 3.167 & 3.167 \\
\hline $\mathbf{1 4}$ & 3.222 & 4.214 & 3.833 & 4.556 & 2.333 & 4.667 \\
\hline $\mathbf{1 5}$ & 2.667 & 3.286 & 2.5 & 2.556 & 2.5 & 3.333 \\
\hline $\mathbf{1 6}$ & 4.444 & 4.286 & 3.667 & 4.111 & 4.667 & 4.667 \\
\hline & & & & & &
\end{tabular}




\begin{tabular}{ccccccc}
\hline $\mathbf{1 7}$ & 3.111 & 2.786 & 3.667 & 3.111 & 3.5 & 3 \\
\hline $\mathbf{1 8}$ & 3.222 & 3.428 & 3.667 & 3.111 & 2.167 & 3.667 \\
\hline $\mathbf{1 9}$ & 3.556 & 3.786 & 3.833 & 3.556 & 4.167 & 3.833 \\
\hline Total & $\mathbf{6 7 . 1 1 1}$ & $\mathbf{6 7 . 2 8 6}$ & $\mathbf{6 8 . 3 3 3 3 3}$ & $\mathbf{6 7 . 7 7 8}$ & $\mathbf{6 6 . 3 3 3}$ & $\mathbf{6 9 . 5}$
\end{tabular}

The Table 1 comprises the students' mean scores in each part of the questionnaire. After analyzing the mean scores, the language learning strategies used by the English Department students can be referred. On the other hand, the number of English Department students using certain language learning strategies is presented on Table 2.

Table 2. The EFL Students' Use of Language Learning Strategies

\begin{tabular}{cc}
\hline Language Learning Strategy & Number of Students \\
\hline Memory & 3 \\
\hline Cognitive & 1 \\
\hline Compensatory & 3 \\
\hline Metacognitive & 3 \\
\hline Affective & 2 \\
\hline Social & 3 \\
\hline Mixed & 4 \\
\hline
\end{tabular}

\subsection{Results of non-English Department Students' Questionnaire}

The result of questionnaire taken from non-English Department students of UIN Maulana Malik Ibrahim is as shown in Table 3.

Table 3. The non-English Department Students' Use of Language Learning Strategies (Mean Score)

\begin{tabular}{ccccccc}
\hline \multirow{2}{*}{ Students } & \multicolumn{7}{c}{ Mean } \\
\cline { 2 - 7 } & Part A & Part B & Part C & Part D & Part E & Part F \\
\hline $\mathbf{1}$ & 2.556 & 2 & 2.667 & 3 & 2.5 & 3.5 \\
\hline $\mathbf{2}$ & 3 & 3.428 & 3.833 & 3.333 & 3.5 & 3.333 \\
\hline $\mathbf{3}$ & 3.333 & 3.143 & 3 & 3 & 3.167 & 3 \\
\hline $\mathbf{4}$ & 3.333 & 3.214 & 3.833 & 3.222 & 3 & 3.5 \\
\hline $\mathbf{5}$ & 1.667 & 2.428 & 1.667 & 2.889 & 3.833 & 1.667 \\
\hline $\mathbf{6}$ & 3.556 & 4 & 3.833 & 4.111 & 3.667 & 3.833 \\
\hline
\end{tabular}




\begin{tabular}{ccccccc}
\hline $\mathbf{7}$ & 3.556 & 2.857 & 2.833 & 3.444 & 3.5 & 3.5 \\
\hline $\mathbf{8}$ & 3.444 & 3.357 & 3.5 & 3.778 & 3.333 & 3.333 \\
\hline $\mathbf{9}$ & 3.111 & 3.286 & 3.5 & 3 & 4 & 2.667 \\
\hline $\mathbf{1 0}$ & 2.889 & 3.214 & 3.333 & 3.778 & 3 & 2.667 \\
\hline $\mathbf{1 1}$ & 3.333 & 3.286 & 3.5 & 3.444 & 3.333 & 3.5 \\
\hline $\mathbf{1 2}$ & 3.556 & 2.928 & 3.167 & 4 & 3.833 & 4.167 \\
\hline $\mathbf{1 3}$ & 3.444 & 3.143 & 4 & 3.889 & 3.5 & 3.667 \\
\hline $\mathbf{1 4}$ & 2.889 & 3.5 & 4.167 & 3.556 & 2.667 & 3 \\
\hline $\mathbf{1 5}$ & 3.222 & 2.714 & 3 & 3.111 & 3.333 & 3.5 \\
\hline $\mathbf{1 6}$ & 3.778 & 3.428 & 3.5 & 3.667 & 3.667 & 3.667 \\
\hline $\mathbf{1 7}$ & 2.667 & 2.928 & 3 & 2.667 & 3.333 & 2.667 \\
\hline $\mathbf{1 8}$ & 3.222 & 3.5 & 3.333 & 3.222 & 3.333 & 3.333 \\
\hline $\mathbf{1 9}$ & 3.333 & 3 & 2.667 & 2.444 & 2.333 & 2 \\
\hline Total & $\mathbf{5 9 . 8 8 9}$ & $\mathbf{5 9 . 3 5 7}$ & $\mathbf{6 2 . 3 3 3}$ & $\mathbf{6 3 . 5 5 6}$ & $\mathbf{6 2 . 8 3 3}$ & $\mathbf{6 0 . 5}$ \\
\hline
\end{tabular}

The Table 3 comprises the non-English Department students' mean scores in each part of the questionnaire. After analyzing the mean scores, the language learning strategies used by the students can be referred. The number of students using certain language learning strategies is presented on Table 4.

Table 4. The non-English Department Students' Use of Language Learning Strategies

\begin{tabular}{cc}
\hline Language Learning Strategy & Number of Students \\
\hline Memory & 4 \\
\hline Cognitive & 1 \\
\hline Compensatory & 4 \\
\hline Metacognitive & 3 \\
\hline Affective & 3 \\
\hline Social & 3 \\
\hline Mixed & 1
\end{tabular}

From the first previous mean score table (Table 1), it is inferred that social strategy is most used by the English Department students of Brawijaya University. The mean score is leading by 69.5. In contrast, the strategy which is less used by these English Department 
students is affective strategy. At the same time, from the mean score Table 2, it is inferred that metacognitive strategy is most used by the non-English Department students of UIN Maulana Malik Ibrahim. The mean score is leading by 63.556. Otherwise, the cognitive strategy is apparently less used by the non-English Department students.

Table 3 and 4, however, do not bluntly represent the dominant use of a strategy. It only describes the individual number of students who use certain strategy in first place. The decision is still determined by the mean scores of each strategy since some students employ mixed strategies or indecisive.

\section{DISCUSSION}

After analyzing the data, most students are found using certain strategy in English language learning. However, some other students are also found to have mixed strategy to help them learning English. It explains that it is possible for students to employ more than one strategy to learn a foreign language.

As stated previously, social strategies are very dominant for English Department students. It shows that English Department students prefer to ask questions, request assistance, and collaborate with other people when they are learning English. Question items which best describe these students are pointed in item 47 and 50 ("I practice SL with other students"; "I try to learn about the culture of SL speakers"). On contrary, English Department students seem to employ affective strategies the least. It clarifies that managing emotions and motivation is not a popular strategy for English Department students to learn English. One example of question item which implicates affective strategies is "I notice if I am tense or nervous when I am studying or using SL" (item 42).

It is a fact that, for English Department group, social strategies dominate the other strategies. However, the greatest mean-score item taken from their questionnaires is actually from memory strategies (item 2). It says "I use new SL words in a sentence so I can remember them". It indicates that putting English words in sentences is the best strategy for English Department students to remember new English words autonomously although not many of them employ the other memory strategies. Contradictory, memory strategies turn out to have an item which has the lowest mean score among other items (item 6). It states "I use flashcards to remember new SL words". It implicates that many English Department students prefer to learn English by inserting English words in sentences so they can memorize them, but using flashcards is not considered an effective strategy for English Department students to learn English. 
The fact that Malang English Department students employ the social strategies the most supports Hoseini and Tabatabaei's (2014) study. However, some other studies mentioned that English Department students use meta-cognitive strategies more frequently than the other strategies. Sari, Sofyan, and Hati (2018) showed that meta-cognitive strategies were dominantly used by the students of English Education in University of Bengkulu. Another study by Alfian (2021) also found that the most strategies reported by the learners were categorized into metacognitive strategies.

The claims about the frequent use of meta-cognitive strategies are actually in accordance with the data results showed in non-English Department group. In Hoseini and Tabatabaei (2014), Iranian ESP students prefer cognitive strategies the most, yet the present study denotes that Malang non-English Department students use metacognitive strategies more often. It tells that strategies such as identifying learning style preferences and needs, planning for an L2 task, gathering and organizing materials, monitoring mistakes, and evaluating success are preferred by the non-English Department students to manage their overall learning process. One example of question item belong to metacognitive strategies is "I try to find as many ways as I can to use my SL". In opposite to metacognitive strategies, Malang non-English Department students do not seem to use cognitive strategies frequently. It means that most non-English Department students will not do strategies of which they manipulate the language materials in direct ways, such as reasoning, analyzing, note-taking, summarizing, synthesizing, outlining, organizing schemas, practicing in naturalistic settings, or practicing structures and sounds formally. One example of question item belong the strategies is "I practice the sounds of SL".

Analyzing each item in non-English Department questionnaires, it is found that an item of compensatory strategy has the greatest mean score above all. It says "to understand unfamiliar SL words, I make guesses”. It indicates that guessing is the strategy employed most often by non-English Department students to learn English. On the other hand, a strategy which is less applied by many non-English Department students is arranging schedules for studying English (item 34). It says "I plan my schedule so I will have enough time to study SL".

As can be seen from the results, English Department and non-English Department students in this study utilize different strategies to help them learning English. The existence of this difference is also denoted in the previous study by Hoseini and Tabatabaei (2014). Many studies, in fact, do not signify the difference in the use of language learning strategies 
between non-English Department and English Department students. All subjects of English learners, regardless the setting and the purpose, generally use meta-cognitive strategies more frequently than the other strategies. Lestari and Wahyudin (2020) who conducted a study on English Literature students showed that metacognitive has been the most frequently used strategies. Lestari and Fatimah (2020) also showed how the meta-cognitive strategies are used dominantly by the students of English Language Education. Furthermore, the frequent use of meta-cognitive strategies is also manifested in Ramadhana, Muth'im, and Sutiono (2020) study on English Department students. Last, Melvina, Lengkanawati, and Wirza (2020) who investigated secondary school students also confirmed the meta-cognitive strategies as the most frequently used by students. A slightly different result was represented in the study of language learning strategies used by the local tour guides at National Park of Bromo Tengger Semeru by Sakinah, Degeng, and Sahiruddin (2020). The result showed that the most frequent strategy used was compensation strategies. The use of compensation strategies by the tour guides are very reasonable as the job requires the subjects to speak to public. Syafryadin, Martina, and Salniwati (2020) stated that "compensation strategies are extremely useful as guidance to avoid communication gap in speaking activities". The different setting and purpose are likely the cause of the result difference in the study.

Grounded on the findings, English teachers/lecturers should help their students to learn successfully and develop their learning autonomy. It is important for both English Department and non-English Department lecturers in subjecting the students regarding the learning background differences of each. The English lecturers are expected to provide sufficient and appropriate materials and methods to teach English while considering the students' needs.

\section{CONCLUSION}

It is a necessity for every English learner to make use of at least one strategy to learn the language. The learning strategies will enhance students to acquire and master the language well and effectively. This study provides empirical evidences to the research questions and presents a fact that English Department and non-English Department students, who share the different cultural learning background, utilize different learning strategies. English Department students prefer social strategies than other strategies. In opposite, nonEnglish Department students prefer metacognitive strategies than other strategies. It indicates that English Department students tend to work with others and understand the target culture 
as well as the language. Meanwhile, non-English Department students tend to manage their overall learning process when they are learning English.

Regarding the present study that indicated the significant use of social strategies by the English Department students, lecturers who teach English in English Department settings can apply methods of study groups inside the classrooms so that English Department students can interact and practice English directly with their friends. The methods are expected to be able to boost English Department students' skills more effectively. In opposite, lecturers who teach English in non-English Department settings should be more active in helping students how to regulate and manage their learning process consciously for their tendencies in using meta-cognitive strategies.

However, due to the limitations of the study, the results were not quite able to represent the generalization. Thus, it is suggested for future researchers who are willing to conduct the similar research to include a larger amount and variety of data so that generalization can be made more reliable. The future studies are expected to manage more research subjects, in this case the students of English Department and non-English Department, for comparison to figure out how far actually the different background of the English learners can affect their choices of learning strategies. Thereby, the findings can provide the readers a lot of useful knowledge in understanding the language learners' attitude towards their learning strategies.

\section{REFERENCES}

Alfian. (2021). The favored language learning strategies of Islamic University EFL learners. Studies in English Language and Education, 8(1), 47-64. https://doi.org/10.24815/siele.v8i1.17844

Alqahtani, A. A. \& Alhebaishi, S. M. (2010). Language learning strategies in an ESP context: A study of political sciences students. MJAL, 2(6), 467-477. Retrieved from https://www.academia.edu/4279347/Language_learning_strategies_in_an_ESP_context _A_study_of_political_sciences_studentsLanguage_learning_strategies_in_an_ESP_co ntext_A_study_of_political_sciences_students

Ang, S., Embi, M. A., \& Yunus, M. M. (2017). Strategies of successful English language learners among private school students. Jurnal Pendidikan Humaniora, 5(2), 47-57. http://dx.doi.org/10.17977/um030v5i22017p047

Cong-Lem, N. (2019). Language learning strategies among Vietnamese EFL High School students. Indonesian JELT 14(1), 55-70. 
http://dx.doi.org/10.25170\%2Fijelt.v14i1.1345

Ellis, R. (1997). Second language acquisition. Oxford: Oxford University Press.

Hapsari, A. (2019). Language learning strategies in English language learning: A survey study. Lingua Pedagogia, Journal of English Teaching Studies, 1(1), 58-68. https://doi.org/10.21831/lingped.v1i1.18399

Hoseini, H. \& Tabatabaei, O. (2014). EFL and ESP learners' use of language learning strategies: A study of collocations. Journal of Language Teaching and Research, 5(1), 112-120. Retrieved from http://ojs.academypublisher.com/index.php/jltr

Lestari, M. \& Wahyudin, A. Y. (2020). Language learning strategies of undergraduate EFL students. Journal of English Language Teaching and Learning, 1(1), 25-30. https://doi.org/10.33365/jeltl.v1i1.242

Lestari, T. M. \& Fatimah, S. (2020). An analysis of language learning strategies used by EFL student teachers at English Language Education Program Universitas Negeri Padang. Journal of English Language Teaching, 9(1), 333-345. https://doi.org/10.24036/jelt.v9i1.108314

Masyhud. (2018). Promoting lesson study at English for Specific Purposes (ESP): Teacher's best practice context. Celtic: A Journal of Culture, English Language Teaching, Literature and Linguistics, 5(2), 36-44. https://doi.org/10.22219/celtic.v5i2.7618

Melvina, Lengkanawati, N. S., \& Wirza, Y. (2020). EFL learners' language learning strategies: Field specialization and gender. International Journal of Education, 13(2), 63-69. https://doi.org/10.17509/ije.v13i2.20972

Oxford, R. (1990). Language learning strategies: What every teacher should know. New York: Newbury House.

Oxford, R. \& Burry-Stock, J. A. (1995). Assessing the use of language learning strategies worldwide with the ESL/EFL version of the Strategy Inventory for language Learning (SILL). System, 23:153-175.

Putri, Z. M., \& Wahyuni, E. (2019). Vocabulary learning strategy employed by high-achiever university students at Malang. Celtic: A Journal of Culture, English Language Teaching, Literature and Linguistics, 6(1), 78-89.

https://doi.org/10.22219/celtic.v6i1.8759 
Ramadhana, D., Muth'im, A., \& Sutiono, C. (2020). Language learning strategies used by English for foreign language students. Lingua Educatia, 2(4), 258-276. Retrieved from http://jtam.ulm.ac.id/index.php/gej/article/view/637

Sakinah, Y. L., Degeng, P. D. D., \& Sahiruddin. (2020). Language learning strategies employed by EFL learners in a rural area. Journal of Applied Linguistics and Literature, 5(1), 26-38. https://doi.org/10.33369/joall.v5i1.9739

Sari, P. Y., Sofyan, D., \& Hati, G. M. (2018). Language learning strategies used by successful students of the English Education study program at University of Bengkulu. Journal of Education and Teaching, 2(4), 68-75. https://doi.org/10.33369/jeet.2.4.68-75

Sartika, D. H. M., Santihastuti, A., Wahjuningsih, E. (2019). The Learning Strategies Used by EFL Students in Learning English. IJEE (Indonesian Journal of English Education), 6(1), 10-20. https://doi.org/10.15408/ijee.v6i1.12111

Syafriadin, Martina, F., \& Salniwati. (2020). Compensation strategies in speaking activities for non-English department students: Poor and competent speakers. Journal of English Educators Society, 5(2), 109-116. https://doi.org/10.21070/jees.v5i2.819

Yustitiasari, H., Junining, E., \& Sahiruddin. (2020). The Relationship between Language Learning Strategies used by Vocational Students and Level of Proficiency. e-Journal of Linguistics, 14(1), 128-136. https://doi.org/10.24843/e-j1.2020.v14.i01.p13 